\title{
REPRESENTATION OF RELIGIOUS AND MORAL VALUES IN THE ENGLISH TEXTBOOK FOR INDONESIAN JUNIOR HIGH SCHOOL: A CDA INVESTIGATION
}

\author{
Ahmad Nadhif*
}

\begin{abstract}
:
This research aims to examine the construction of the discourse of religious and moral values within the official English textbook for Indonesian high school students and to expose the underlying ideology. The textbook analyzed is the official English textbook for junior high school grade VII, Bahasa Inggris: When English Rings the Bell. This study makes use of Fairclough's three dimensional models, namely textual, processing, and socio-cultural analysis. In the level of textual analysis, the researcher addresses the issues of transitivity and modality. In the processing stage, the focus is on the issue of assumption. Meanwhile, the ideology investigation is done in the last level. The findings shows that the discourse of the religious and moral values are classified into four main categories: values toward one's self (e.g being disicpline regarding the time), values toward others (e.g loving them and being attentive to their occupation and physical appearance), values toward animals (i.e. loving and being attentive to them), and values toward things around (i.e. being attentive to them). The Critical Discourse Analysis (CDA) investigation reveals that the discourse of religious and moral values within this book represents some dominating ideologies, such as the western-secular way of greeting people, the outschool activites of the mid-high social class, the rich's-style house furniture, and the notion that beauty is identical with white skin and straight hair, the capitalism-driven economics system, as well as the idea of woman emancipation by the feminist movement.
\end{abstract}

Keywords: Textbook analysis, Critical Discourse Analysis (CDA) 


\section{INTRODUCTION}

These recent years, issues of character education have marked a significant shift in Indonesian national curriculum. Although the spirit of character building has been surely inserted in the national educational curriculum from the earliest version and explicitly stated in the national objective of education (chapter 3 of UU 2003), and despite the wide acceptance that moral formation of students is one of the foundational goals of formal education (J. Dewey, ${ }^{1} \mathrm{~J}$. Goodlad, ${ }^{2}$ J. F. Goodman \& H. Lesnick, ${ }^{3}$ A. McClellan, ${ }^{4}$ K.A.Strike, ${ }^{5}$ ) it is only in this recent times character building issues gains a lot of public concern. Besides the official policies from the government, Indonesian educators (such as Budimansyah et al., ${ }^{6} \mathrm{D}$. Kesuma, et al, ${ }^{7}$ M. Rohman, ${ }^{8}$ E. Sulistyowati, ${ }^{9}$ M. Yamin, ${ }^{10}$ and D. Zuchdi, et al.,${ }^{11}$ to mention some) have made some contributions on the discussion of character building.

This unprecedented great concern on character building is partly triggered by the insignificant execution of character shaping in Indonesia. ${ }^{12}$ It is signaled by the considered bad characters prevalent

1J. Dewey, Moral Principles in Education (Carbondale, IL: Southern Illinois University Press, 1909)

${ }^{2} \mathrm{~J}$. Goodlad, The Moral Dimensions of Schooling and Teacher Education. Journal of Moral Education, vol.2 (1992). 87-98.

${ }^{3}$ J. F. Goodman \& H. Lesnick, The Moral Stake in Education: Contested Premises and Practices (New York: Longman, 2001)

${ }^{4}$ A. McClellan, Schools and The Shaping of Character: Moral Education on America 1607-Present, Clearing House for Social Studies (Bloomington: University of Indiana Press, 1992)

${ }^{5}$ K. A. Strike, "School, Community and Moral Education", in Nucci and Narvaez (Eds.) Handbook of Moral and Character Education (New York and London: Routledge, 2008)

${ }^{6}$ Budimansyah, et al. Model Pendidikan Karakter di Perguruan Tinggi: Penguatan PKn, Layanan Bimbingan Konseling, dan KKN Tematik di Universitas Pendidikan Indonesia. (Bandung: No Publisher, 2010)

${ }^{7}$ D. Kesuma, et al. Pendidikan Karakter: Kajian Teori dan Praktik di Sekolah. (Bandung: ROSDA, 2012)

${ }^{8}$ M. Rohman, Kurikulum Berkarakter (Jakarta: Prestasi Pustaka, 2012)

${ }^{9}$ E. Sulistyowati, Implementasi Kurikulum Pendidikan Karakter (Yogyakarta: PT. Aji Citra Parama, 2012)

${ }^{10} \mathrm{M}$. Yamin, Ideologi dan Kebijakan Pendidikan: Menuju Pendidikan Berideologi dan Berkarakter (Malang: Madani, 2013)

${ }^{11}$ D. Zuchdi, et al. Model Pendidikan Karakter (Yogyakarta: Multi Presindo, 2013)

${ }^{12}$ Budimansyah, Model... 
nowadays in the country manifested in various wrongdoings such as corruption, intolerance, free sex, and violence. ${ }^{13}$ Many people therefore demand the government increase the quality of character building in formal education. Understandably, if it is true that today's Indonesia is typified by moral value crisis or "ethical illiteracy" among its citizens, ${ }^{14}$ it should be noted then, as Elhanan suggests it is partly the product of yesterday's educational system. ${ }^{15}$ Noddings urges educators to recognize that "although no individual can escape responsibility for his own actions, neither can the community that produced him escape its part in making him what he has become". ${ }^{16}$ In this regard, Alwasilah notes,

As public debates on politics grow intensely, many critics point their fingers at education, which, in their judgment, has failed to provide people with knowledge, skills, and wisdom. If education had fulfilled its duty, critics assert, social ill such as corruption, collusion and nepotism would not be so rampant. ${ }^{17}$

Thus, character education "has become such a prominent issue in education because it has become obvious that our current educational system is not helping our students develop sound moral characters". ${ }^{18}$

Theoretically, the purposes of a state are advanced in the goals of education. As suggested by M. Carnoy, a commonly used instrument for educational system to instill values and attitudes that are considered to be worth in the social structure is ideology. ${ }^{19}$ In Indonesian context, more than merely targeting individual

${ }^{13}$ Kesuma, Pendidikan...

${ }^{14}$ Budimansyah, Model...

${ }^{15}$ Elhanan, "The Denial of Palestinian National and Territorial Identity In Israeli Schoolbooks Of History And Geography 1996-2003”, in Dolon \& Todoli (eds) Analysing Identities In Discourse. (Philadelphia: John Benjamins Publishing Company, 2008), 77-110.

${ }^{16} \mathrm{~S}$. Winton, "Character Education: Implications for Democracy". International Critical Childhood Policy Studies, Vol.1 (2008). 42-63.

${ }^{17}$ Emilia, A Critical Genre-Based Approach to Teaching Academic Writing in A Tertiary EFL Context in Indonesia (Unpublished doctoral thesis: the University of Melbourne, 2005), 13.

${ }^{18}$ In-Jae Lee, "The Proper Directions and Practical Ways for Character: Education in the Korean Elementary School", Asia Pacific Education Review Vol. 2 (2001). 72-84.

${ }^{19} \mathrm{M}$. Carnoy, "Education, Economy, and The State". In M. Apple (ed.), Cultural And Economic Reproduction: Essays on Class, Ideology, and The State (Bruxeles: Didier, 1982), 70-126. 
students, the project of character education also serves to construct Indonesian national identity considering that the character crisis Indonesia is facing now is in other words identity crisis. It is stated in Pengembangan Budaya dan Karakter Bangsa (p.6) that awareness of one's self and his or her nation's identity is an important part in the project. Moreover, among the function of this project (p.7) is not only to filter foreign cultures but also Indonesia's own cultures that contradict the culture and character values of the nation which are dignified ("bermartabat"). This is thus the nature of the concept of identity. Elhanan states that "the discourse of identity is also the discourse of difference, inclusion and exclusion", the construal of which "includes strategies of denying other identities that seem threatening". ${ }^{20}$

Indeed, therefore, as stated by James Arthur, character education is likely the most conflicting battleground of ideology in educational world. ${ }^{21}$ While the function of education is to shape human being into what they should be, is likely already a consensus, the whatthey-should-be is another case. ${ }^{22}$ In J. Graham et al's words, "We all want children to grow into good people, but ideas of this 'good' vary considerably". ${ }^{23}$ Different world views would have different ideals in educating people. In Nucci and Narvaez's words, "[t]his apparent support for moral education, however, masks the considerable forms of practice that would constitute this area of education". ${ }^{24}$ In Purpel's words, the current character education movement "represents an ideological and political movement rather than a debate about curricular and instructional matters". ${ }^{25}$

\footnotetext{
${ }^{20}$ Elhanan, The Denial, 78.

${ }^{21}$ James Arthur, Education with Character: the Moral Economy of Schooling (London: Routledge Falmer, 2003)

${ }^{22}$ Philip H. Phenix, Realm of Meaning: a Philosophy of the Curriculum for General Education (California: Princarft, Inc., 1986)

${ }^{23} \mathrm{~J}$. Graham, et al., "Ideology and Intuition in Moral Education", European Journal of Developmental Science [EJDS]. 2 (3), 2008, 269-286.

${ }^{24}$ L.P.Nucci, \& D. Narvaez, Handbook of Moral and Character Education (New York: Routledge, 2008), 1.

${ }^{25}$ P. Smagorinsky, \& J. Taxel, "The Discourse of Character Education Ideology and Politics In The Proposal and Award of Federal Grants". Journal of Research in Character Education, 2(2), 2004, 113-140
} 
Different educational ideologies are present due to the fact that educators, philosophers and politicians, hold different beliefs about its purposes and how it should be put into operation. ${ }^{26}$ As also emphasized by A.S.Bryk et al. "Public Education is not value neutral; its values mirror those of our larger society". ${ }^{27}$ Louis Althusser, ${ }^{28} \mathrm{P}$. Bourdieu and J. Passeron, ${ }^{29}$ and S. Bowles and H. Gintis, ${ }^{30}$ suggest that educational system does not only provide knowledge and skill but also reproduce certain social structures and repress different voices. Education can silence dissident voices or push them out if they choose to rebel. ${ }^{31}$

Considering that Indonesian government release many educational materials for the project of character education, including textbooks (discussed below), it is worth noticing the statement of J. Anyon, although dealing with history text, that the content of educational materials is determined by an ideological perspective. ${ }^{32}$ The content of these materials can "... acquire the status of truth, and the information will be less likely to be subjected to scrutiny in classrooms or compared with other points of view". Green, Weade and Graham state that the form and content of instructional materials are organized and put forward with a specific focus in mind and in turn can potentially shape and give direction to students' perception. ${ }^{33}$ In H. Giroux's words, "texts and social practice function primarily to legitimate the interests of the dominant social order" ${ }^{34}$ The language of the text

${ }^{26}$ David Hicks, "Radical Education", in S. Ward, (ed). Education Studies: A Student Guide (Routledge Falmer, 2004)

${ }^{27}$ A. S. Bryk, et al., Catholic Schools and the Common Good (Cambridge, 1993), 319.

${ }^{28}$ Louis Althusser, "Ideology and Ideological State Apparatuses", in L. Althusser Lenin and Philosophy, and Other Essays. Trans. Ben Brewster (London: New Left Books, 1971), 127-188.

${ }^{29} \mathrm{P}$. Bourdieu, \& J. Passerson, Reproduction in Education, Society and Culture (London: Sage, 1977)

${ }^{30}$ S. Bowles, \& H. Gintis, "Capitalism and Education in the United States", in M. Young \& G. Whitty (eds.), Society, State, and Schooling: Reading on The Possibilities for Radical Education (Guilford, Surrey: Falmer, 1977), 192-227.

${ }^{31}$ M. Fine, Framing Dropouts (NY: State University of New York, 1991)

${ }^{32} \mathrm{~J}$. Anyon, "Ideology and united states history textbooks". Harvard Educational Review. (1979), 363.

33J. Green, et al. "Lesson Construction and Student Participation: A Sociolinguistic Analysis". In J. Green and J. Harker (eds.), Multiple Perspectives of Analyses of Classroom Discourse (Norwood, NJ: ablex, 1988)

${ }^{34} \mathrm{H}$. Giroux, Theory and Resistance in Education: A Pedagogy for The Opposition (New York: Bergin \& Garvey, 1983), 157. 
may constitute a tool for promoting the acceptance of domination. M. Bakhtin makes clear that language is the terrain where ideological intensions and hegemonic practices are realized. ${ }^{35} \mathrm{He}$ states that

Language is not an abstract system of normative forms but rather a concrete heteroglot conception of the world. All words have the "taste" of a profession, a genre, a tendency, a party, a particular work, a generation, an age group, the day and hour. Each word tastes of the context...in which it has lived its socially charged life; all words and forms are populated by intentions.

Thus, it is a myth that English or any other language can avoid politics, as suggested by Phillipson. He explains that the language being taught in the classroom is inextricably linked to economic, political, and social reality in which it develops, although language can hide the interests being promoted.

On the other hand, It has been a long time ago that many experts expose the crucial role of textbook in teaching and learning process. Philip G. Altbach, reported that the only books students have access to are often textbooks. ${ }^{36} \mathrm{~J}$. Patrick, ${ }^{37} \mathrm{M}$. Lockheed \& A. Verspoor, ${ }^{38}$ and P. Altbach,et $\mathrm{al}^{39}$ found out that there is a tendency that textbooks are the main teaching medium in classrooms. Sheldon and Hutchinson as quoted by Wang, ${ }^{40}$ verify that many programs of ELT (English Language Teaching) rely on what the textbooks serve. In 2001, Anita Lie states that in spite of the suggestion of developing innovative activities and making use of other authentic materials, it is textbooks that typically convey the curriculum in Indonesia. Furthermore, Anna Maria Pinter ${ }^{41}$ also confirms that textbook is the most significant material for teaching-

${ }^{35}$ M. Bakhtin, The Dialogic Imagination (C. Emerson \& M. Holquist, Trans.) (Austin, TX: University of Texas, 1990), 293.

${ }^{36}$ Philip G. Altbach, "Textbooks: The International Dimension" In APPLE/CHRISTIAN. SMITH, (1991), 242-258.

${ }^{37}$ J. Patrick, High School Government Textbook. ERIC Digest, ED301532, December, (1988)

${ }^{38} \mathrm{M}$. Lockheed, \& A. Verspoor, Improving Primary Education in Developing Countries: a Reveiw of Policy Options (Washington, D.C.: World Bank, 1990)

${ }^{39} \mathrm{P}$. Altbach, et al. Textbooks In American Society: Politics, Policy and Pedagogy (Albany, NY: State University Press, 1991)

${ }^{40} \mathrm{~J}$. Wang, Evaluating an EFL Textbook-A New English Course [online]. Available online at: http://www.ling.lancs.ac.uk/groups/crile/docs/crile31wang.pdf (10 august 2013)

${ }^{41}$ Annamaria Pinter, Teaching Young Language Learners (Oxford: Oxford University Press, 2006) 
learning process that guides teachers' and learners' activities in many classrooms. According to Graves in M. Sohoriti, textbook functions as the backbone of many courses. ${ }^{42}$ Textbooks, therefore, hold a very important role in the teaching and learning process as they are the main references for teachers to conduct the instruction activities in classroom.

In line with the above considerations, this research aims to examine the construction of the discourse of religious and moral values within the official English textbook for junior high school grade VII, Bahasa Inggris: When English Rings the Bell, written by Asep Gunawan, Yuli Rulani Khatimah, dan Siti Wachidah and edited by Emi Emilia, Didi Suherdi, dan R. Safrina. The textbook is comprised of 188 pages, divided into 8 chapters. This textbook is released by The Ministry of Education and Culture based on the national curriculum of 2013. and to expose the underlying ideology of the textbook.

This study makes use of Fairclough's three dimensional model, which brings together three related levels of analysis, namely textual (description stage), processing (interpretation stage), and sociocultural analysis (explanation stage). In the level of textual analysis, the researcher addresses the issues of transitivity and modality. In the processing stage, the focus is on the issue of assumption. Meanwhile, the ideology investigation is done in the last level.

\section{FINDINGS}

This part presents firstly the religious and moral (or called character) values contained in the textbook, and then how these values are analyzed through the lense of CDA.

\section{The construction of religious and moral values mainly contained in the textbook}

These various religious and moral values can be categorized into four more general classification: values related to one's self, to other people, to animals, and to the things around. This is how the discourse of religious and moral values, as pescribed by the character-buildingbased curriculum of 2013, is constructed within the textbook. This is ilustrated in the following diagram.

${ }^{42}$ M. Sohoriti, An Analysis of The Indonesian National Textbook: English For Senior High School, Book 3 For The Third Year Natural And Social Science Programs (Unpublished Master Thesis: International islamic University of Malaysia, 2005)

Kodifikasia, Volume 11 No. 1 Tahun 2017 


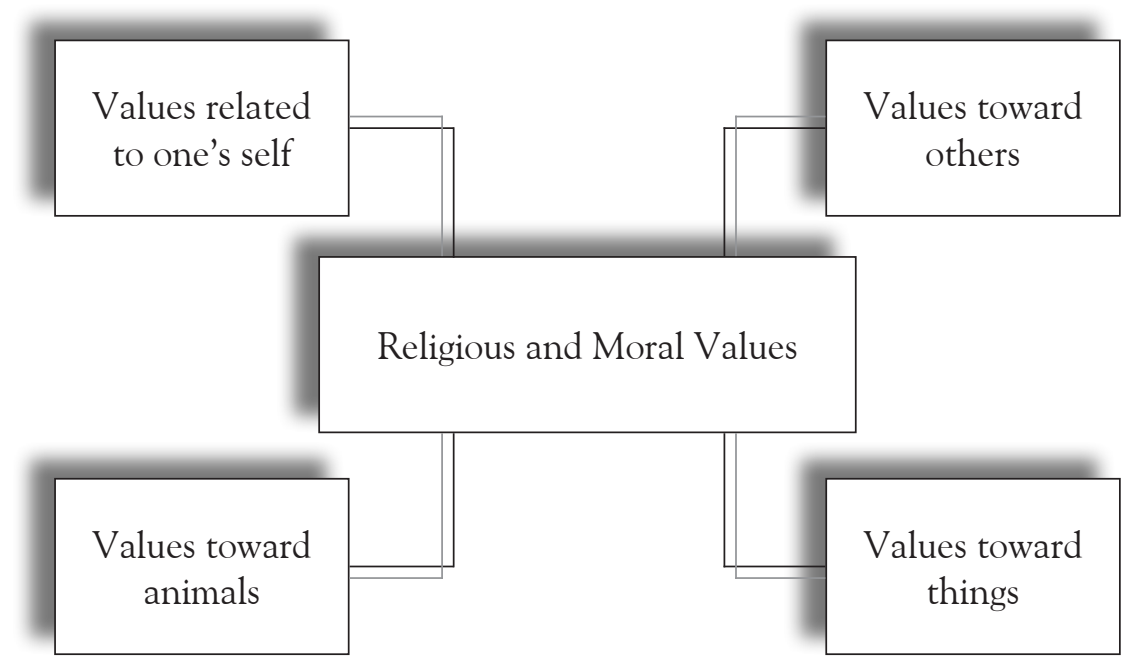

From the general values above, the researcher further assumes more specific values. For examples, habit of greeting people implies the values of friendliness, politeness, and love. Attentiveness to time and signs potentially conveys the values of discipline, diligence and responsibility. Attentiveness to people, animals, plants, and things around is likely to mean that the students should love them and take care of them. Moreover, especially in the topic of being attentive of people, the researcher also finds texts containing the values of helpfulness, thankfulness, cheerfulness, forgiveness, and diligence.

\section{Underlying ideologies behind the discourse of religious and moral values}

The CDA investigation will be divided based on the four cateories of character values above.

\section{Values related to one's self}

Values related to one's self seems to be focused on chapter II of the textbook, which is about attentiveness to time. Here, values of discipline and diligence are apparently encouraged. In this chapter, the topics such as daily activities and subjects schedule at school are discussed.

Being discipline and diligent is of course generally favorable. However, there is no such kind of free-value values. The following is the textual, assumption, and ideological analysis of the topic of daily activities presented on the textbook. 
It is illustraed in the textbook that when the teacher asks a student to tell the class about his daily activities, he answers:

On Monday, I play football

On Tuesday, I learn to play guitar

On Wednesday, I go jogging

On Thursday, I go to the library

On Friday, I visit my grandmother

On Saturday, I go swimming

On Sunday, I go to the park.

$$
\text { (p. 34) }
$$

All these sentences are categorized as material process within the system of transitivity, which position the subject "I" (i.e. the student) as the actor and "football, playing guitar, jogging, and swimming" as the range; while "the library" and "the park" are the circumstance of place. The word "my grandmother" is the only target of those sentences.

Meanwhile, in the lens of modality, these are categorized of modalization of usuality. Without any modal auxiliaries, these sentences fall into the category of polarized (or unmodulated) statement, which means that the speaker is 100\% certain of he says.

In the level of assumption analysis, there is a value assuption that the activities of playing football, learning to play guitar, going jogging, going to the library, visiting a grandmother, going swimming and going to the park are are acceptable, or maybe even favorable, activities. These are the represented activities outside school of Indonesian students. This is certainly not representation of all groups of socio-economic status of Indonesian students. Only those of midhigh class students have privilege to routinely do such "amusing" activities.

Those who live a mid-low-class life, especially those who live the countryside area, are unlikely represented. Students within this socio-economic level usually spend their after-school time and their day-offs to help their parents work.

Another group who is also excluded from this daily-activities representation is those who spend their after-school time to study at the diniyah madrasahs. Students belonging to this group is not few. Several months ago, hundred of thousand people protested the full- 
day school policy proposed by the Ministry of Education. Their main argument is that the policy will potentially disturb their schedule of studay at the madrasahs.

\section{Values toward others}

Loving and being attentive seem to be the emphasis of the values toward others. These values are elaborated in chapter I (entitled "How are You?"), chapter III (entitled "I love People around Me"), chapter V (entitled "I Love my Town"), and chapter VI, which is entitled "She's so Nice". The following is the discussion on the habit of greeting people as an expression of loving them and the character of being attentive toward them.

\section{Greeting people as an expression of love}

Chapter I is likely devoted to instill the habit of greeting people around. The chapter is opened with a question from an adult man seeming to be a teacher: "Did you say 'Good Morning' to your family this morning?"

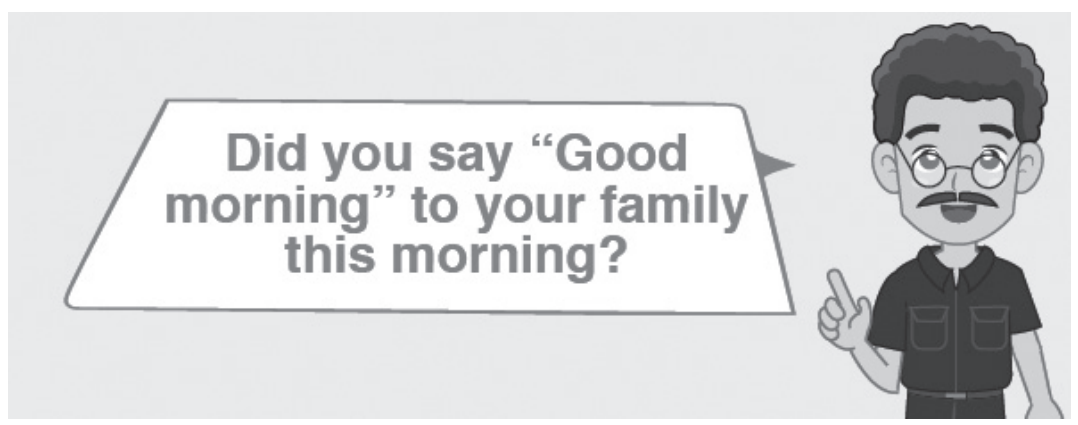

(Pic. 4.1 Taken from the textbook, page 2)

This verbal process with "you" (i.e students) as the sayer, "Good morning" as the verbiage, and "your family" as the target, conveys the value assumption that saying "Good morning" at morning to family members is a good thing and therefore should be done by the students.

This notion is then continued with examples of how this way of greeting people are practiced in a daily basis as expressed within the following pictures. 

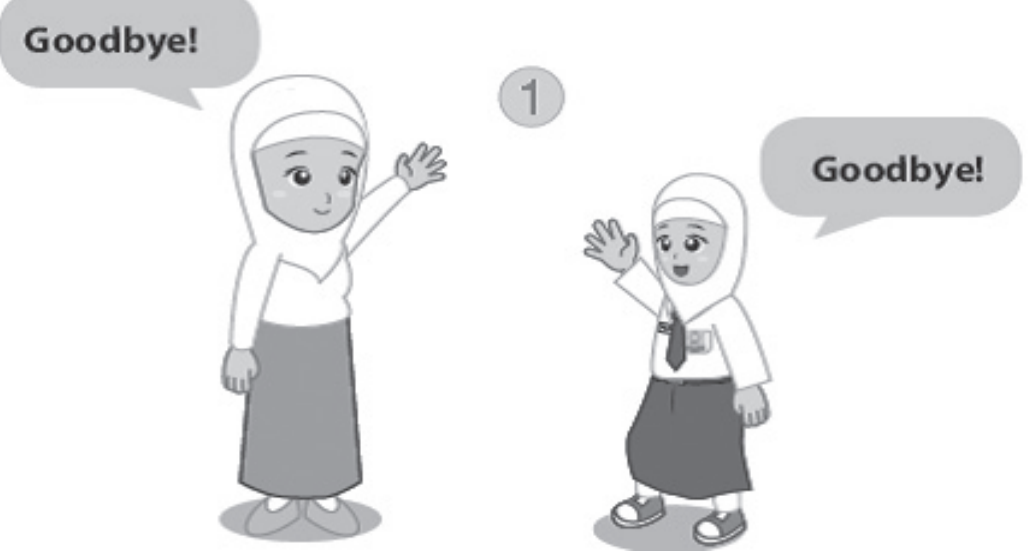

(Pic. 4.2 Taken from the textbook, page)

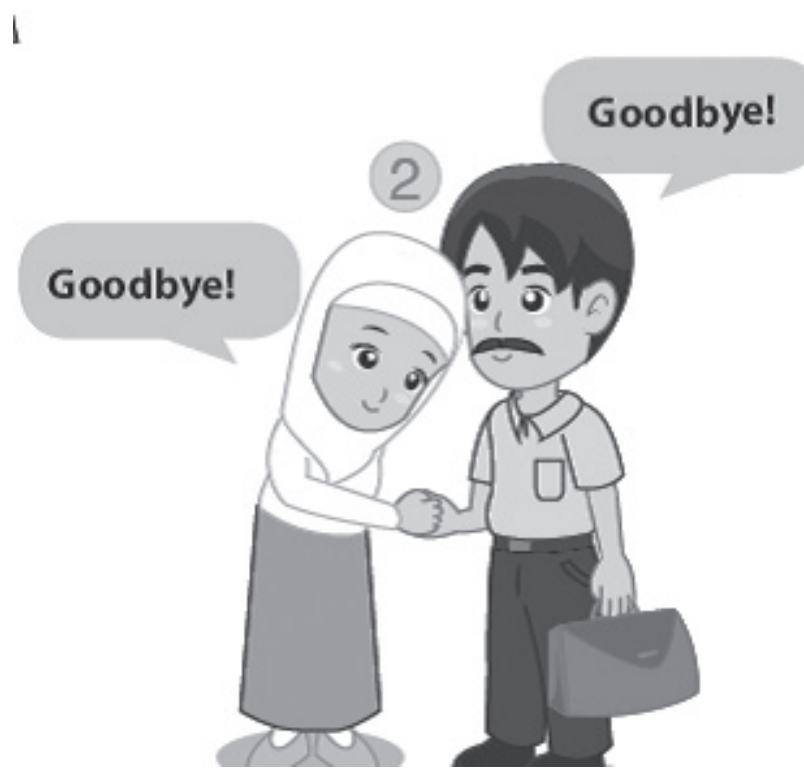

(Pic 4.3 Taken from the textbook, page 4) 


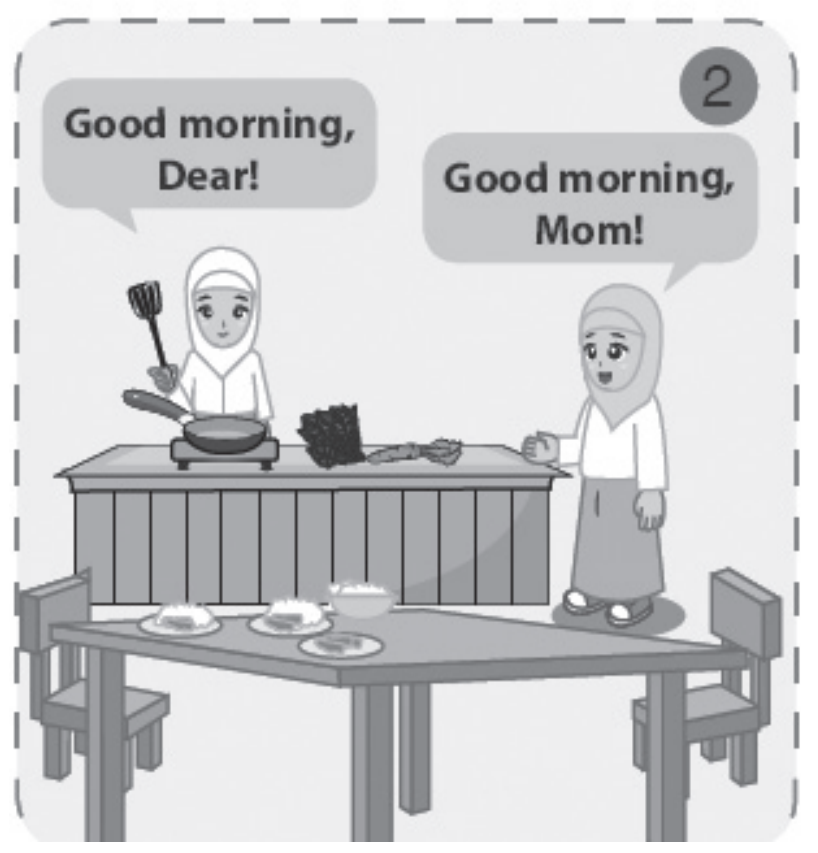

(Pic. 4.4 Taken from the textbook, page 5)

Greeting people is a normal activity for human being with any socio-ideological identity. The way to greet people, nevertheless, varies among them. In 1987, Indonesian society was shocked by Gus Dur statement while interviewed by Amanah Magazine that the Islamic greeting "Assalamu'alaykum" could be changed with "Selamat pagi", "Selamat siang", "Selamat sore", and "Selamat malam". This controversial statement triggered a huge protest from Muslim masses, and even KH As'ad Samsul Arifin, who previously paved the way for Gus Dur to be the chairman of PBNU, dubbed him as a kyai ketoprak" ${ }^{43}$.

In the lens of Islamic teaching, a specific utterance is prescribed for greeting people. There are so many hadiths explaining this matter (see Sunan Abu Dawood/2721, Shahih Bukhariy/3045, and Shahih Muslim/2447 to mention some). For example,

وروى الترمذي أن النبي صلى الله عليه وسلم قال :إذا لقي الرجل أخاه المسلم فليقل : السلام عليكم ورحمة الله وبركاته 
And_Tirmidziy reported that the Prophet pbuh said: "if a man encounter with his brother he should say 'Assalamu 'alaykum warahmatullaahi wabarakatuhu'44.

It is, therefore very strange to see a muslim family greet each other using "good morning" and "goodbye" instead of "assalamu'alaykum" like shown in Pic 4.2, 4.3, 4.4, and 4.5 above. Here, consciously or not, Islamic greeting is suppressed although Islamic dresses is clearly represented. The problem even precisely lies on the people portrayed with Islamic dresses while they greet each other using non-Islamic greetings, which are the greetings belonging to the secular western cultures.

\section{Being attentive to people}

The people being the target of attention are mostly about the occupation of the members of family and the physical appearence of classmates.

\section{Attentiveness to people's occupation}

The occupations represents the mid-high class of socio-economic status. The pic 4.6 shows that the mother is a policewoman; the father is a gardener (and also a biology teacher, as explained at page 106); the grandfather is a doctor; and the grandmother is a cook and a restaurant owner (as explained at page 106).

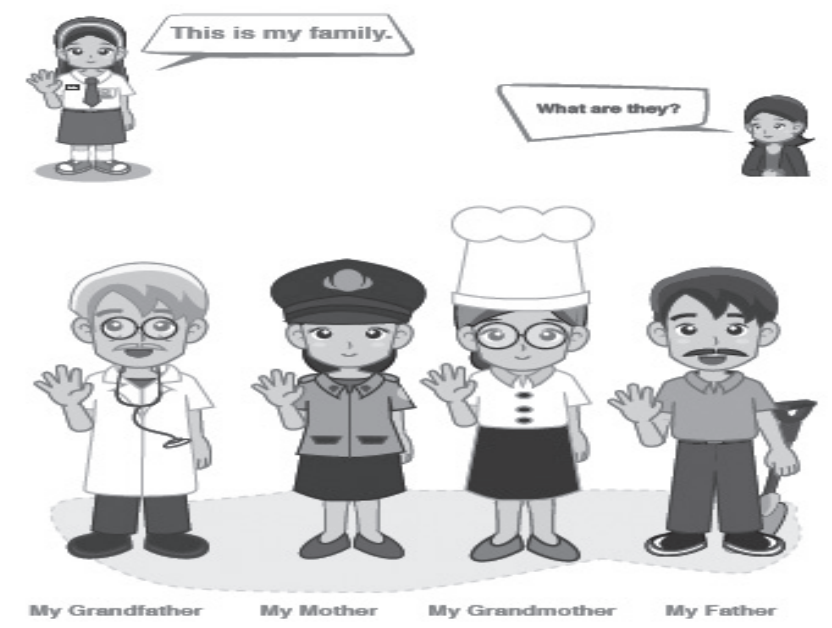

(Pic. 4.6 Taken from the textbook, page 103)

${ }^{44}$ Sunan at-Tirmidziy/2721 
Moreover, this portrayal also represents the modern notion of gender equality which suggests women have job as men do.

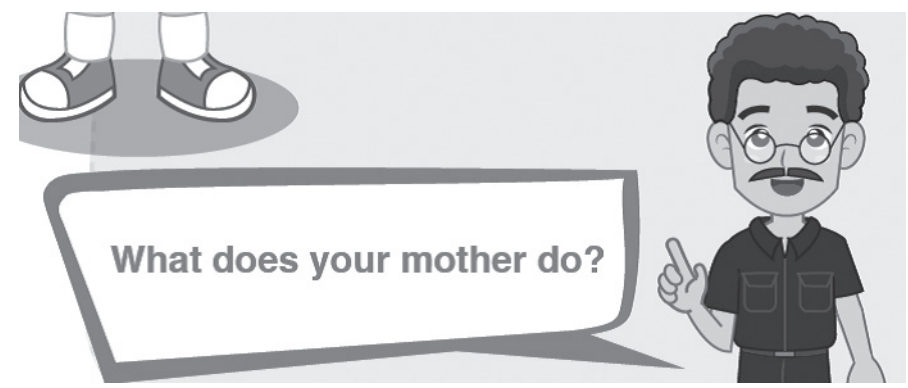

(Pic. 4.7 Taken from the textbook, page 102)

The process material "do" in the question "What does your mother do?" (see pic 4.7 above) involves a propositional assumption that the mother has an occupation. And as shown in pic. 4.8, the student then gives an answer: "My mother is a policewoman", expressed in an attributive relational process, in which "my mother" is the carrier and "policewoman" is the attribute. In the lens of modality system, it is categorized as unmodalized certainty due to its lack of any modal.

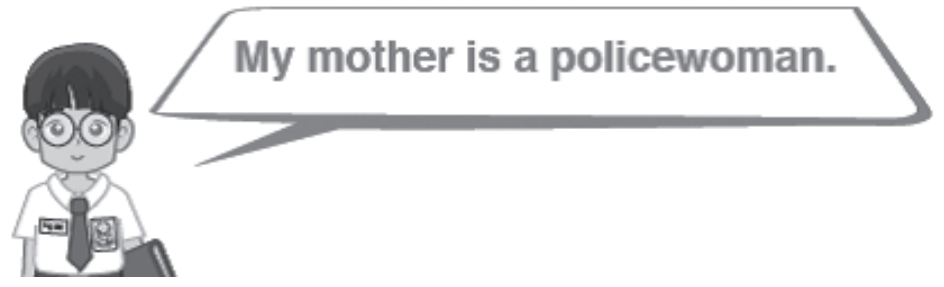

(Pic. 4.8 Taken from the textbook, page 119)

The mother, as a policewoman, is also shown as joining the program called "The Police are Kids' Best Friend" (see Pic. 4.9), an attributive relational process and unmodalized certainty, suggesting a value assumption that police are favorable occupation; while in reality, for some if not many Indonesian people, police institution is famous for its usual bribery in traffic-rules transgressions and is also known for its brutality in managing what they call "terrorism" acts. 

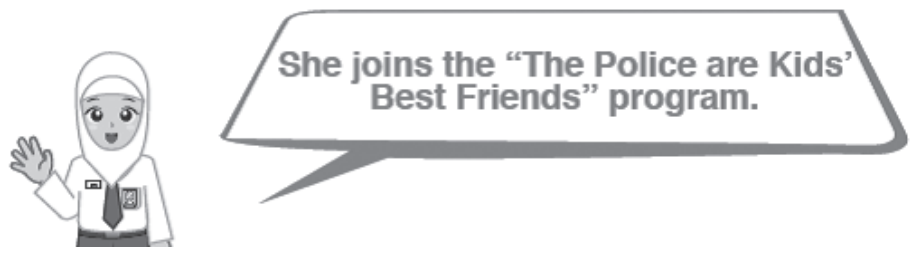

(Pic. 4.9 Taken from the textbook, page 120)

Another portrayal of the mother as a policewoman is that "she protects the town from crime". Besides amplifying the above notion of woman emancipation by putting a "she" as the actor of the material process "protects", this sentence also conveys a value assumption that this kind of act is favorable. Interestingly, this act of protecting the town from crime is symbolized by an image of the policewoman saving a bank from a male criminal.

\section{Attentiveness to people's physical appearance}

Here, the researcher focuses on the concept of beauty the textbook ideologically conveys through its statements and their accompanying images.

From more than 400 pictures of women contained throughout the textbook, only 2 of them represent the dark-skinned and curlyhaired women! These 2 pictures (see Pic 4.11) are pictures of the same person, who is a mother, instead of a young girl. Moreover, they are only pictures without any description of their physical appearance, let alone being attributed with any description of beauty.

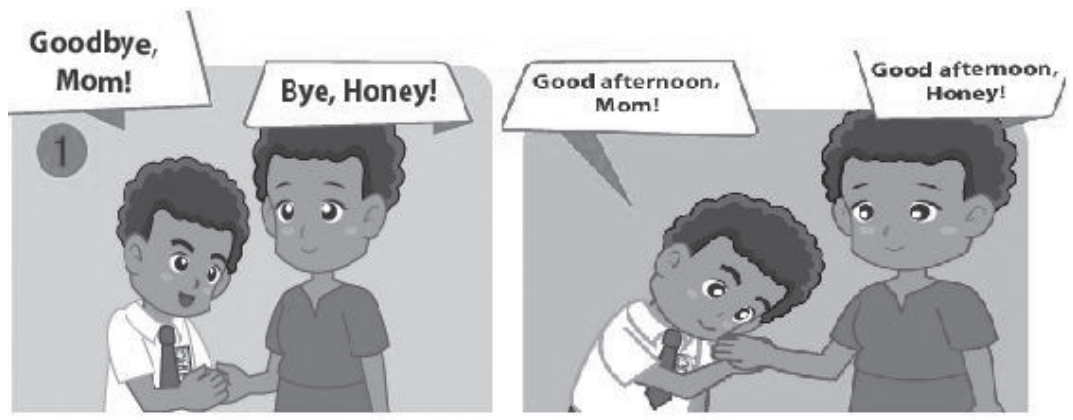

(Pic. 4.11 Taken from the textbook, page 15 and 17)

Meanwhile, the rest of the pictures represent the white-skinned and straight-haired women, and some of them are attributed with favorable adjectives like beautiful and pretty! 
In page 130 (see Pic. 4.11), a girl with a veil describes her whiteskinned friend as follows.

She's tall

Her hair is straight

Her skin is smooth

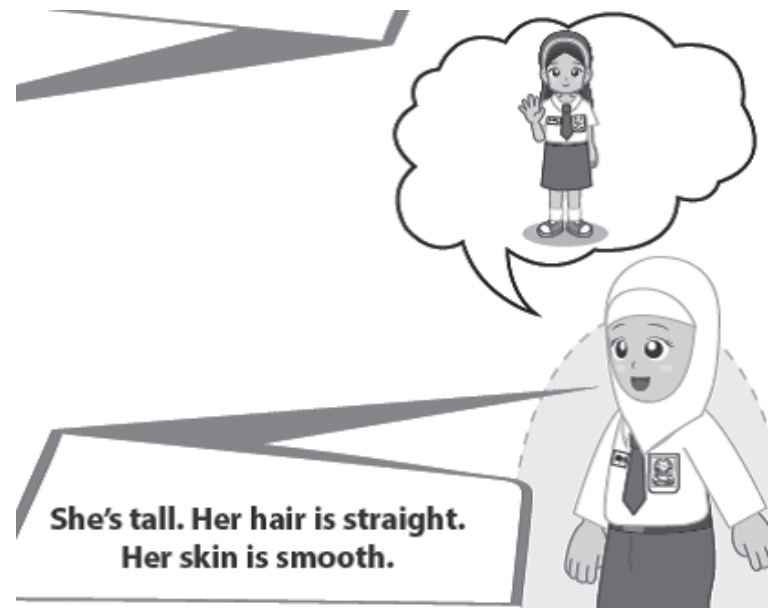

(Pic. 4.12 Taken from the textbook, page 130)

All of the above sentences are written in attributive relational process. The carriers are "she", "her hair", and "her skin"; while the attributes are "tall", "straight", and "smooth", conveying value assumption that they are desirable. Without any modals, these three sentences imply $100 \%$ of certainty and, hence, are categorized as unmodalized affirmations.

The following picture (pic. 4.13) keeps the same notion. A young girl named Lina is recognized in an attributive relational process with an attribute "a pretty girl", and it is stated with 100\% (unmodalized) belief. The associated picture shows that the pretty girl is straighthaired and bright-skinned.
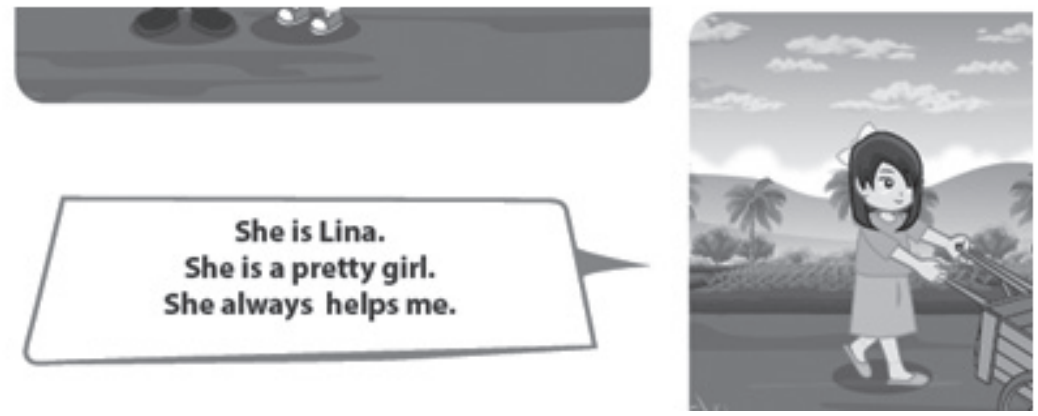

(Pic. 4.13 Taken from the textbook, page 148) 
Moreover, this pretty girl is then associated with her pleasing character of being helpful. The sentence "She always helps me" is a material process, in which the pretty girl is the actor and "me" is the goal. The modal "always" suggests that the action "help" is perceived as a high usuality by the writer. This also transmits a value assumption that the action is favorable. Thus, the girl is not only physically pretty but also ethically beautiful; and her skin is bright and her hair is straight.

Furthermore, Pic 4.14 strengthens the notion that beauty is identical with bright skin and straight hair. The mother who is attributed as a beautiful woman is portrayed in the image version as bright-skinned and straight-haired.

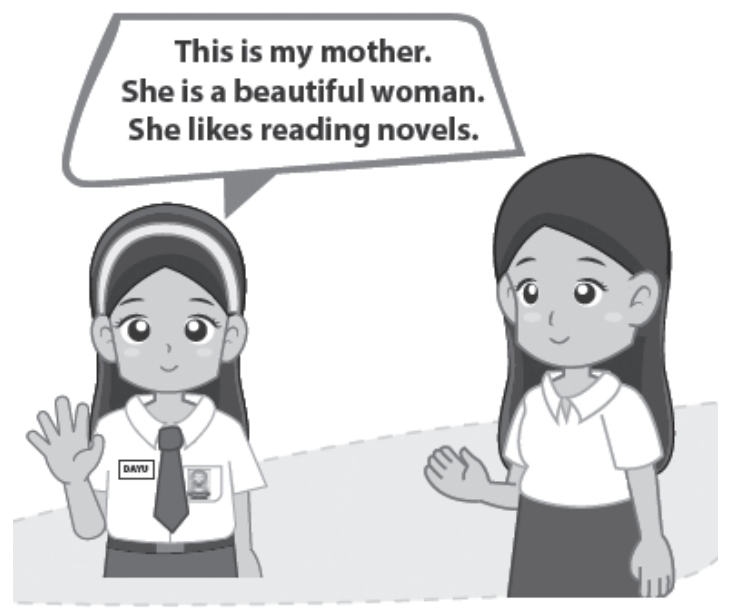

(Pic. 4.14 Taken from the textbook, page 152)

Interestingly, this "beautiful" mother is characterized as "likes reading a novel". This mental process "likes" and "reading novel" as the phenomenon. And as for the modality analysis, due to its lack of any modal, the statement is categorized is unmodalized certainty, implying that the speaker is $100 \%$ assured about it. When this liking reading novel is attributed to a mother, who is additionally beautiful, it brings the postulation that this hobby is favored. However, reading novels is not common activity of ordinary mothers in Indonesia, especially those living in the mid-low social class.

Not only that, the notion that being beautiful is identical with bright skin and straight hair is again amplified in Pic. 4.15. The boy states, 
This is my friend

She is beautiful

We go to school together

(p. 152)
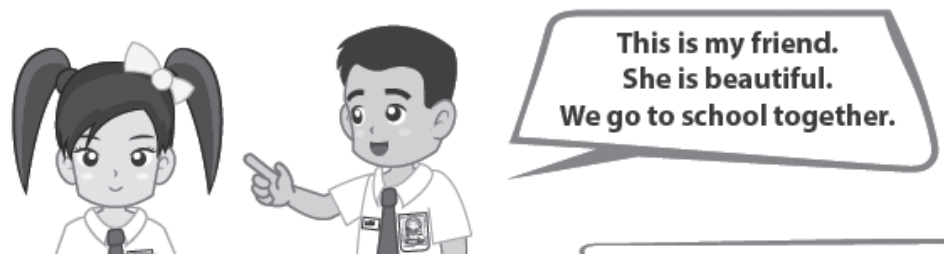

(Pic. 4.15 Taken from the textbook, page 152)

It is puzzling whether the unmodalized material process "we go to school together" has a causal-effect relationship with the previous attributive relational process "she is beautiful". If yes, then this picture conveys a somewhat dangerous message: the boy goes to school together with the girl because the girl is beautiful, i.e she has bright skin and straight hair!

\section{Values toward things}

In line with the representation of the people's occupation discussed above, the discourse of character value of being attentive to things around does represent the mid-high social class. Written in uniformly identifying relational process, the clauses are completed with images showing the luxurious things inside the house owned by the speaker.

In the living room, which is spacious and clean, there are a bookcase, a TV, a painting, among others.

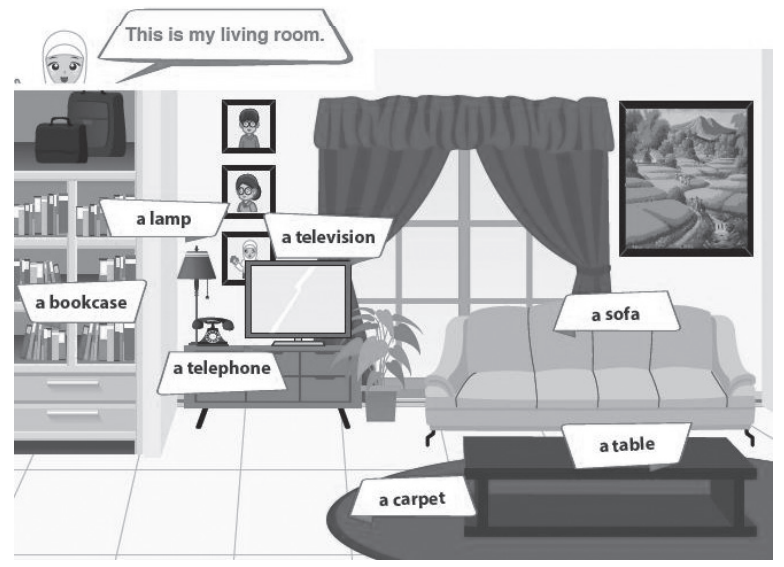

(Pic. 4.15 Taken from the textbook, page 83) 
The wide kitchen is equipped with a refrigerator, a cabinet, an oven, a sink, etc., plus a set of a dining table with the chairs.

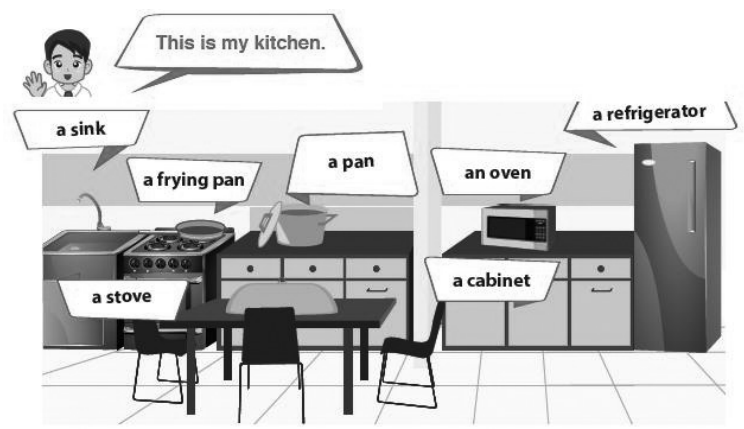

(Pic. 4.16 Taken from the textbook, page 84)

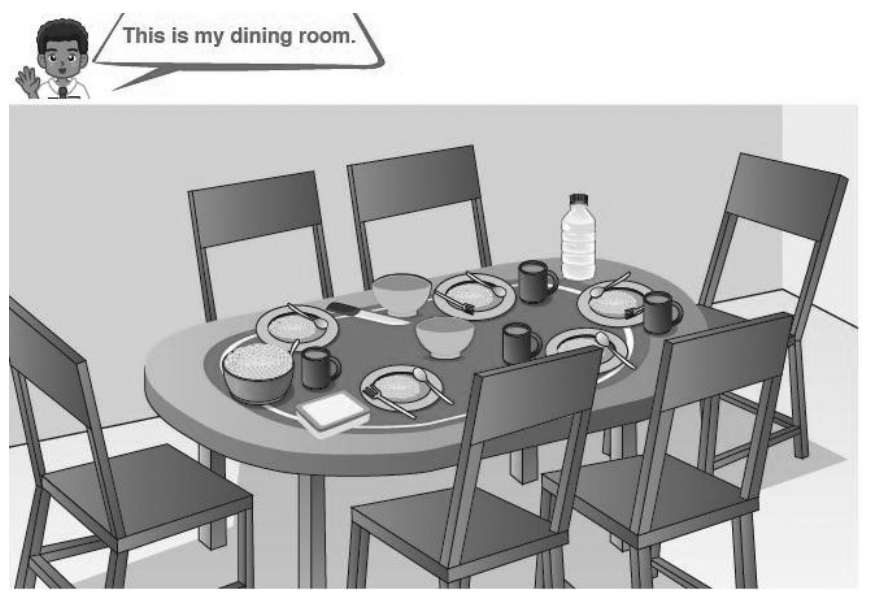

(Pic. 4.17 Taken from the textbook, page 85)

Furthermore, while many Indonesian students share their bedrooms with their brothers and sisters, pic 4.18 shows a student has her own bedroom, which is large, and completed much furniture. 


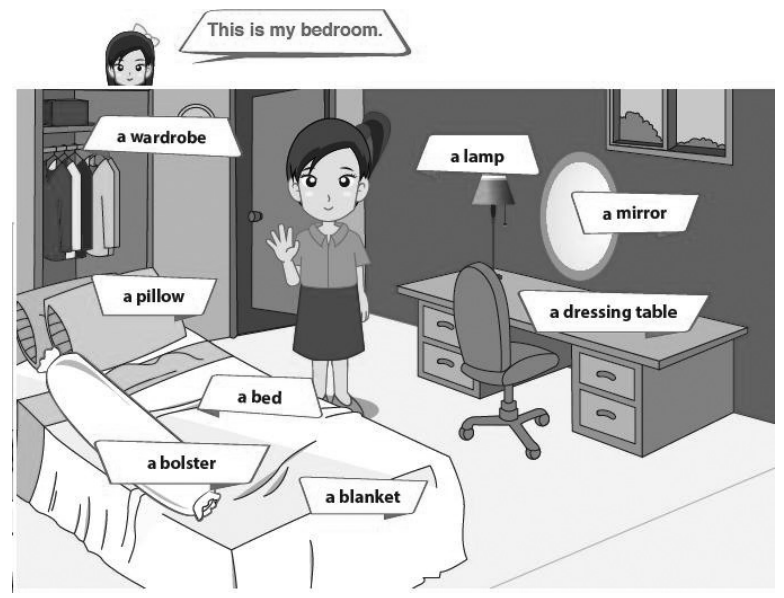

(Pic. 4.18 Taken from the textbook, page 86)

The mid-high social class is also represented in the pic 4.19 until pic. 4.20. The bathroom is provided with a shower, a sitting toilet, a mirror with the sink, etc.

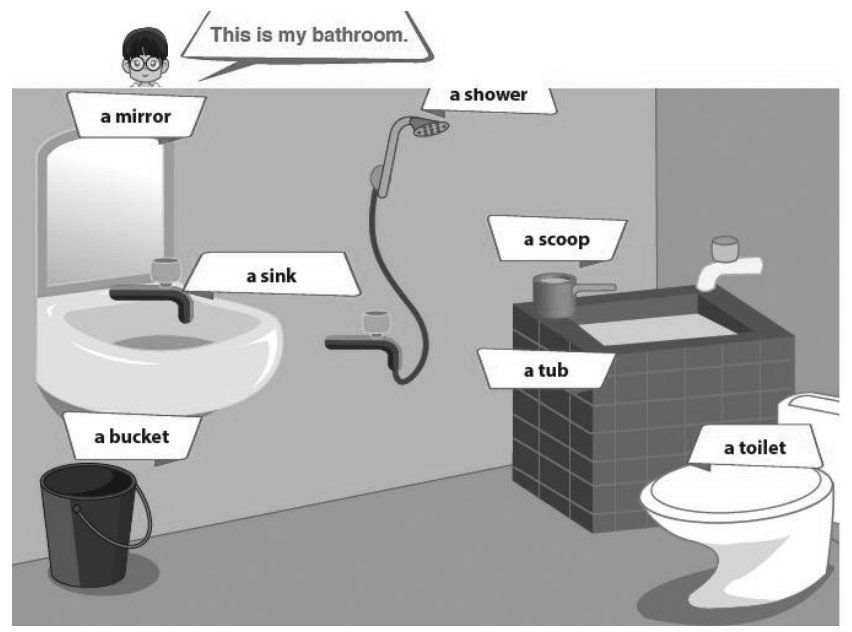

(Pic. 4.19 Taken from the textbook, page 87)

The garage is also large, where a deluxe car, a scooter, and a bike are kept inside. 


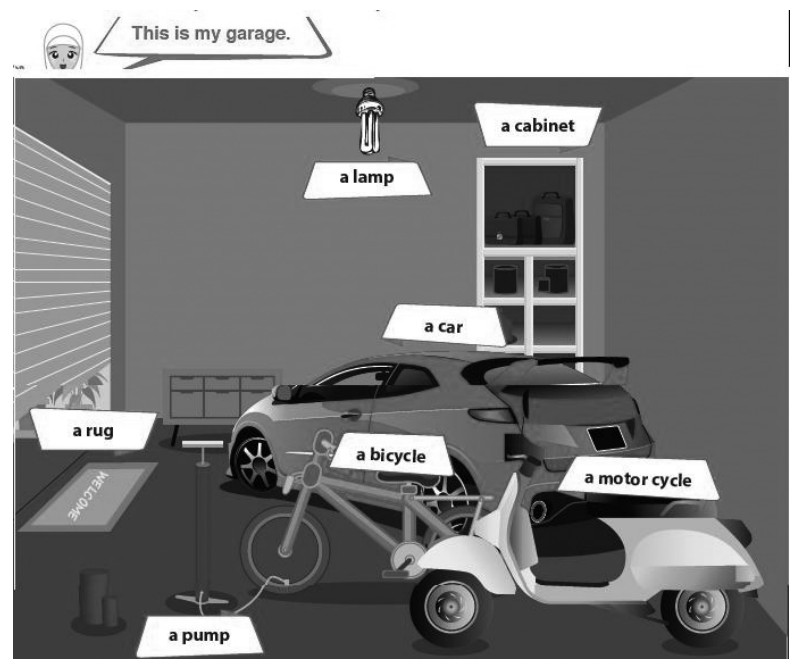

(Pic. 4.20 Taken from the textbook, page 88)

And lastly, the garden is outsize too, representing the wealth of the owner.

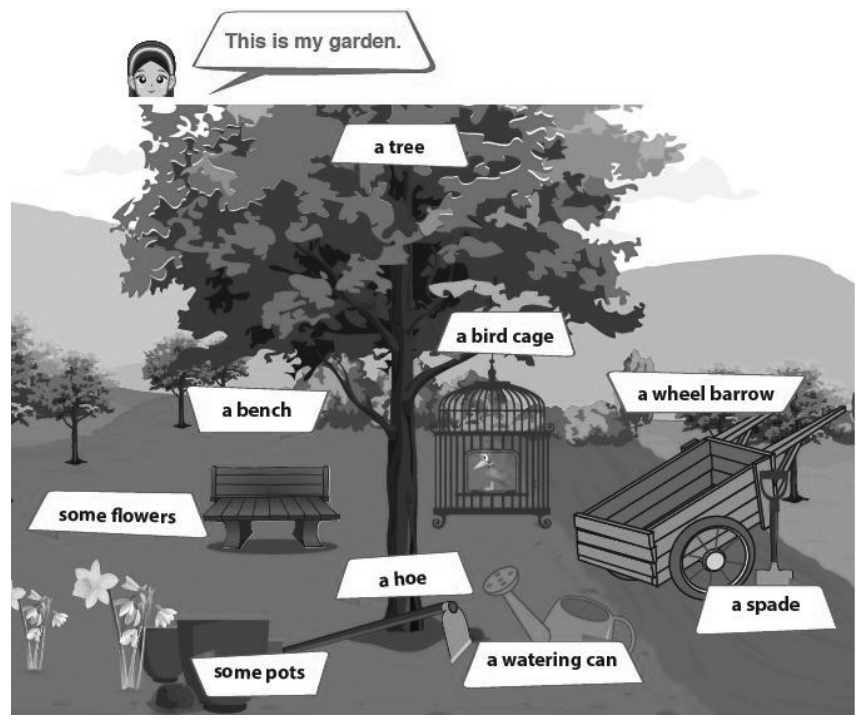

(Pic. 4.21 Taken from the textbook, page 89

\section{CONCLUSION}

The objectives of this research are to examine how the discourse of religious and moral values within the official English textbook for Indonesian high school students is constructed and to expose the underlying ideology. This is done through a rigid textual analysis 
targeting the systems of transitivity and modality, and a processing analysis through the examination of the assumptions conveyed extra linguistically by the texts, and explanation analysis through ideological analysis relating the texts with the social order within which the texts are produced.

The findings show that the discourse of religious and moral values within the textbook is constructed with generally four main categories of values: values related to one's self, to other people, to animals, and to the things around.

From the general values above, the researcher further assumes more specific values. For examples, habit of greeting people implies the values of friendliness, politeness, and love. Attentiveness to time and signs potentially conveys the values of discipline, diligence and responsibility. Attentiveness to people, animals, plants, and things around is likely to mean that the students should love them and take care of them. Moreover, especially in the topic of being attentive of people, the researcher also finds texts containing the values of helpfulness, thankfulness, cheerfulness, forgiveness, and diligence.

The CDA investigation then exposes the ideological representation the discourse transmits. The themes of being attentive to time, to people's occupations, and to the things around, bring with them the primordial ideological representation of the mid-high social class. Out-school activities such as learning to play guitar, going jogging, going swimming, and going to the park; occupation such as doctor, restaurant owner, policewoman, and modern gardener; and fully-furnished large house with a luxury car undoubtedly do not represent the low socio-economic class of Indonesian students, rather they are representation of that of "the haves".

Moreover, especially within the topic of being attentive to people's occupation, there are two underlying ideological representations that should be highlighted. The first is the primordial ideology of feminism; and secondly, the systemic ideology of capitalism. As for the former, the textbook portrays the adult women within a family as working women: big restaurant owner and a policewoman who caught a male criminal! While for the latter, the discourse is supportive to the systemic ideology of Capitalism by representing the act of protecting the town with saving a bank from robbery. Banks, 
as discussed earlier, are the key players in the capitalist-oriented markets. For the same time, banks are representation of riba-based business, which is categorized as one of the major sins in the lens of Islamic systemic ideology.

Then, regarding to the discourse of expression of love and politeness to people surrounding by greeting them, the text conveys the western-dominated ways of greetings. Even between supposedly Muslim family members, the represented greetings are the western styles, instead of the Islamic ones. Here, the systematic ideological Islamic greeting "Assalamu'alaykum.." is suppressed and marginalized.

These notions are manifested in selective processes of transitivity and certain use of modality system, and in also several conveyed assumptions beyond linguistic features.

\section{REFERENCES}

A. McClellan, A. Schools and The Shaping of Character: Moral Education on America 1607-Present, Clearing House for Social Studies, Bloomington: University of Indiana Press, 1992.

Annamaria Pinter, Teaching Young Language Learners, Oxford: Oxford University Press, 2006.

D. Budimansyah, et al. Model Pendidikan Karakter di Perguruan Tinggi: Penguatan PKn, Layanan Bimbingan Konseling, dan KKN Tematik di Universitas Pendidikan Indonesia, Bandung: No Publisher, 2010.

D. Kesuma, et al. Pendidikan Karakter: Kajian Teori dan Praktik di Sekolah, Bandung: ROSDA, 2012.

D. Zuchdi, et al. Model Pendidikan Karakter, Yogyakarta: Multi Presindo, 2013.

David Hicks, "Radical Education", in Ward, S. (ed). Education Studies: A Student Guide, RoutledgeFalmer, 2004. 
E. Sulistyowati, Implementasi Kurikulum Pendidikan Karakter, Yogyakarta: PT. Aji Citra Parama, 2012.

Elhanan, "The Denial of Palestinian National and Territorial Identity In Israeli Schoolbooks Of History And Geography 1996-2003", in Dolon \& Todoli (eds) Analysing Identities In Discourse, Philadelphia: John Benjamins Publishing Company, 2008.

Emilia, A Critical Genre-Based Approach to Teaching Academic Writing in A Tertiary EFL Context in Indonesia, Unpublished doctoral thesis: the University of Melbourne, 2005.

H. Giroux, Theory and Resistance in Education: A Pedagogy for The Opposition, New York: Bergin \& Garvey, 1983.

In-Jae Lee, "The Proper Directions and Practical Ways for Character: Education in the Korean Elementary School", Asia Pacific Education Review Vol. 2, No. 2, 2001.

J. Anyon, "Ideology and united states history textbooks". Harvard Educational Review, 49 (1979).

J. Dewey, Moral Principles in Education, Carbondale, IL: Southern Illinois University Press, 1990.

J. F. Goodman \& H. Lesnick, The Moral Stake in Education: Contested Premises and Practices, New York: Longman, 2001.

J. Goodlad, The Moral Dimensions of Schooling and Teacher Education. Journal of Moral Education, 21 (2), 1992.

J. Graham, et al. "Ideology and Intuition in Moral Education", European Journal of Developmental Science [EJDS]. Vol. 2, No. 3, 2008.

J. Green, et al., "Lesson Construction and Student Participation: A Sociolinguistic Analysis". In J. Green and J. Harker (eds.), Multiple Perspectives of Analyses of Classroom Discourse, Norwood, NJ: ablex, 1988.

J. Patrick, High School Government Textbook. ERIC Digest, ED301532, December, 1988. 
J. Wang, Evaluating an EFL Textbook—A New English Course [online]. Available online at: http://www.ling.lancs.ac.uk/groups/crile/ docs/crile31wang.pdf (10 august 2013)

James Arthur, Education with Character: the Moral Economy of Schooling, London: Routledge Falmer, 2003.

K.A. Strike, "School, Community and Moral Education", in Nucci and Narvaez (Eds.) Handbook of Moral and Character Education, New York and London: Routledge, 2008.

L.P. Nucci \& D. Narvaez, Handbook of Moral and Character Education. New York: Routledge, 2008.

Louis Althusser, "Ideology and Ideological State Apparatuses", in L. Althusser Lenin and Philosophy, and Other Essays. Trans. Ben Brewster. London: New Left Books, 1971.

M. Bakhtin, The Dialogic Imagination (C. Emerson \& M. Holquist, Trans.), Austin, TX: University of Texas, 1990.

M. Carnoy, "Education, Economy, and The State". In M. Apple (ed.), Cultural And Economic Reproduction: Essays on Class, Ideology, and The State, Bruxeles: Didier, 1982.

M. Fine, Framing Dropouts, Albany, NY: State University of New York, 1991.

M. Lockheed \& A. Verspoor, Improving Primary Education in Developing Countries: a Reveiw of Policy Options, Washington D.C.: World Bank, 1990.

M. Rohman, Kurikulum Berkarakter, Jakarta: Prestasi Pustaka, 2012.

M. Sohoriti, An Analysis of The Indonesian National Textbook: English For Senior High School, Book 3 For The Third Year Natural And Social Science Programs, Unpublished Master Thesis: International islamic University of Malaysia, 2005.

M. Yamin, Ideologi dan Kebijakan Pendidikan: Menuju Pendidikan berideologi dan berkarakter, Malang: Madani, 2013.

P. Altbach, et al., Textbooks In American Society: Politics, Policy and Pedagogy, Albany, New York State University Press, 1991. 
P. Bourdieu \& J. Passerson, Reproduction in Education, Society and Culture (R. Nice, Trans.), London: Sage, 1977.

P. Smagorinsky \& J. Taxel, "The Discourse of Character Education Ideology and Politics In The Proposal and Award of Federal Grants". Journal of Research in Character Education, 2(2), 2004.

Philip G. Altbach, Textbooks: The International Dimension In APPLE/ CHRISTIAN-SMITH, 1991.

Philip H. Phenix, Realm of Meaning: a Philosophy of the Curriculum for General Education, California: Princarft, Inc, 1986.

S. Bowles \& H. Gintis, "Capitalism and Education in the United States", in M. Young \& G. Whitty (eds.), Society, State, and Schooling: Reading on The Possibilities for Radical Education, Guilford, Surrey: Falmer, 1977.

S. Winton, "Character Education: Implications for Democracy". International Critical Childhood Policy Studies, 1(1), 2008.

Sunan at-Tirmidziy 